\title{
Androcentrism and conservatism within climate obstructionism. The case of the think tank CLINTEL in The Netherlands
}

\author{
Androcentrismo y conservadurismo en el obstruccionismo climático. El caso \\ del think tank CLINTEL en los Países Bajos
}

\author{
Mayte Moreno-Soldevila \\ University of Groningen | Broerstraat, 5, 9712 CP, Groningen | The Netherlands | \\ https://orcid.org/0000-0001-6951-8703 | mtmorenosoldevila@gmail.com
}

Dates | Submitted: 28/09/2021 | Accepted: 14/12/2021

\begin{abstract}
Within the climate countermovement, neoliberal think tanks have played a predominant role in both the United States and Europe. There are links between climate obstructionism and ideologies such as conservatism and the extreme right; androcentrism, patriarchal worldviews and industrial masculinities, and whiteness and xenosceptic ideologies. This research takes as a case study the Dutch think tank CLINTEL, which, despite having been founded in 2019, has managed to get a declaration against the climate emergency to members of the European Parliament, which has been signed by climate action contrarians from all over the world. This paper analyses the contrarian framings present in this declaration based on the typology established by Almiron et al. (2020). In addition, this research makes a gendered discursive analysis of the discussion about this statement in a forum of the European Parliament, where CLINTEL met with members of the far-right Dutch party Forum van Democratie (FvD), part of the European Conservatives and Reformists group. The study on CLINTEL's statement shows that the think tank uses similar frames as other European denialist think tanks. Its climate declaration
\end{abstract}

\section{Resumen}

Dentro del contramovimiento climático, los think tanks neoliberales han desempeñado un papel predominante tanto en Estados Unidos como en Europa. Existen vínculos entre el obstruccionismo climático e ideologías como el conservadurismo y la extrema derecha; el androcentrismo, las cosmovisiones patriarcales y las masculinidades industriales, y las ideologías blanca y xenoescéptica. Esta investigación toma como caso de estudio el think tank neerlandés CLINTEL, que, a pesar de haber sido fundado en 2019, ha conseguido hacer llegar a los miembros del Parlamento Europeo una declaración contra la emergencia climática, que ha sido firmada por contrarios a la acción climática de todo el mundo. Este trabajo analiza los encuadres contrarios presentes en esta declaración a partir de la tipología establecida por Almiron et al. (2020). Además, esta investigación realiza un análisis discursivo de género del debate sobre esta declaración en un foro del Parlamento Europeo, donde CLINTEL se reunió con miembros del partido holandés de extrema derecha Forum van Democratie (FvD), que forma parte del grupo de Conservadores y Reformistas Europeos. El estudio sobre la declaración de CLINTEL muestra que el think tank utiliza 
has a significant gender bias, with an overwhelming over-representation of men among the signatories. This, together with the discursive analysis of its discussion with members of the European Parliament, is a contribution to the emerging line of research on industrial masculinities and climate change obstructionism. This paper provides information on the think tank CLINTEL, helping to fill a knowledge gap on the climate change countermovement in the Netherlands.

Keywords: climate crisis, think tanks, denialism, gender, neoliberalism. marcos similares a los de otros think tanks negacionistas europeos. Su declaración sobre el clima tiene un importante sesgo de género, con una abrumadora sobrerrepresentación de hombres entre los firmantes. Esto, junto con el análisis discursivo de su debate con los miembros del Parlamento Europeo, es una contribución a la línea de investigación emergente sobre las masculinidades industriales y el obstruccionismo del cambio climático. Este artículo proporciona información sobre el think tank CLINTEL, contribuyendo a llenar un vacio de conocimiento sobre el contramovimiento del cambio climático en los Países Bajos.

Palabras clave: crisis climática, think tanks, denialism, gender, neoliberalism.

\section{INTRODUCTION}

The rise of Nationalism and Right Wing Populisms in Europe has exacerbated inequalities and discrimination. Patriarchal neoliberal structures are getting fortified by the influence of hegemonic masculinities and conservative ideologies, which oftentimes present themselves in the form of nationalism, emphasizing the importance of closing borders and a rejection of multiculturalism, and often implement neoliberal stances, such as ascribing to and defending free-market autonomy.

Plehwe (2014) indicates that "in recent times, no subject matter has provoked stronger practical science wars than the question of climate change, its human causes and its policy implications" (p. 102). However, these wars implicated in the questioning of climate change are often not scientific, but cultural. Climate change denial is one of the ways in which androcentric, national and Right Wing Populisms engage in the preservation of the status quo and the capitalist system. Despite $99 \%$ of climate expert scientists agreeing on the urgency to act in order to manage the climate crisis (Lynas et al., 2021), conservative political parties as well as some neoliberal think tanks and other organizations are presenting climate action contrarian arguments to the existence, the anthropocentric origins and the impact of the climate crisis. This is especially alarming keeping into account that, even within climate expert groups, economists are pushing legislation towards taking mitigation measures dependent not so much on the urgency of climate action, but on economic issues, the effects of these measures on the free-market, and on the neoliberal system. The existence of a Climate Change Countermovement (CCM) or "denial machine" (Piltz, 2008) further jeopardizes the progress of climate action.

Nationalism, right-wing ideologies, conservatism, neoliberalism, industrial/breadwinner masculinities, and xenosceptic ideologies have been shown to correlate with climate change denial and contrarianism (Almiron et al., 2020; Beder, 2001; Krange et al., 2018; Kahan et al., 2007; Hultman \& Pulé, 2018; Hultman et al., 2019; Kahan et al., 2007; Krange et al., 2018; Kulin et al., 2021; Lockwood, 2018; McCright \& Dunlap, 2011; Plewe, 2014). Most of the research on climate change denialism, politics and climate action contrarian think tanks has been 
developed with a focus on the USA, and although there has recently been research dedicated to European countries, The Netherlands remains underrepresented and under-researched in this regard (Van der Wel, 2019).

However, Right Wing Political Parties which align themselves with climate action contrarianism have grown in March 2021 elections in The Netherlands. Forum van Democratie (FvD) and JA21, both of which have ties to the climate action contrarian Dutch think tank Climate Intelligence Foundation (CLINTEL), have grown from 2 to 8 seats in parliament and from 0 to 3 seats in parliament respectively. Moreover, CLINTEL is a very recent example of a climate action obstructionist think tank in Europe, especially compared to others in neighboring countries, which accentuates the relevance of rising climate action opposition in Europe and, more specifically, in The Netherlands. This think tank was founded in 2019 by professor of geophysics Guus Berkhout and journalist Marcel Crok, and it sustains that "there is no climate emergency". There has been previous research dedicated to many European denialist think tanks such as the Europäisches Institut für Klima und Energie in Germany (founded in 2007), Institut Économique Molinari in France (2003), Centre for Policy Studies in United Kingdom (1974) and more (see Almiron et al., 2020). Nevertheless, CLINTEL is a recently created think tank and therefore there has not been published research about it yet.

This paper outlines a literature review of the previous research focused on the CCM, including climate change denialism and skepticism, and opposition to climate change mitigation policies, in relation to the intersections of gender and political ideology. After that, it uses CLINTEL as a case study to identify the existence or absence of correlation between the available research on think tanks and the climate countermovement and CLINTEL's stances. To do so, CLINTEL's core document will be analyzed, their World Climate Declaration asserting that "there is no climate emergency", as well as a press conference which took place on November $20^{\text {th }}$ of 2019 , hosted by the European Conservatives and Reformists group in the European Parliament.

\section{LITERATURE REVIEW}

\subsection{Consensus on anthropogenic global warming}

There is an overwhelming consensus among expert scientific opinion about global warming being caused primarily by human activity (Lynas et al., 2021). Nevertheless, lobby groups and fossil fuel companies place climate change denialists and international peer-reviewed climate science experts on an equal level of trustworthiness (Hultman \& Pulé, 2018), the media often presents climate change denialist think tanks as independent experts of climate science (Beder, 2001) and only 15\% of the US population accurately estimate the consensus on anthropogenic global warming above $90 \%$ (Leiserowitz et al., 2015). The result is that climate change literacy is jeopardized by a lack of education and accuracy in the representation of the environmental situation, and a CCM that is working to spread doubt on the state of affairs regarding global warming, to delay climate change mitigation policies, and to avoid government regulation and intervention (Oreskes \& Conway, 2011). The climate action contrarian discourse that the CCM uses disseminates "messages advocating against the evidences of human-induced global warming or casting doubt on climate change as a problem to varied degrees" (Almiron et al., 2020, p. 4). These stances are shared not only by bloggers and non-advocacy research organizations, but also by climate change contrarian think tanks, which are considerably more influential (Almiron et al., 2020). 
Think tanks are political actors that seek to sell their points of view in the marketplace of ideas, and they do that by creating and disseminating expert knowledge (Abelson, 2018). To achieve that dissemination of their ideas, they rely on media to spread their outputs or to comment on public affairs as expert sources (Almiron, 2016). Even think tanks themselves are assuming journalistic routines by using their own communicative tools (The Economist, 2014). Despite the ability of think tanks to disseminate pro-elite discourses on a global scale, the communications aspect of these organizations is often one of the least studied (Almiron, 2017). In the study of organized climate obstructionism, the analysis of think tanks as generators of discourse has seminal works in this area of study (Jacques, 2008), and with a growing line of research in recent years (i.e., Almiron \& Xifra, 2020; Almiron et al. 2020; Almiron \& Moreno, 2021; Plehwe, 2021).

In order to dismantle these types of organizations that hinder the progress of urgent and necessary climate action, it is important to look at the causes behind such a climate action contrarian ideology, and this is the area this paper attempts to contribute to. Previous research has found that there are certain intersections of gender and political identities and ideologies that are correlated with CCM. In regards to gender, industrial/breadwinner masculinities are associated to CCM (Hultman \& Pulé, 2018), and in regards to political ideologies, Right Wing Populisms (RWP), Nationalism, Conservatism, and Neoliberalism have been shown to be linked with CCM (Almiron et al., 2020; Beder, 2001; Hultman et al., 2019; Kahan et al., 2007; Krange et al., 2018; Kulin et al., 2021; Lockwood, 2018; McCright \& Dunlap, 2011; Plewe, 2014).

\subsection{Masculinities and the climate change countermovement}

In their book Ecological Masculinities, Hultman \& Pulé (2018) discuss the types of masculinities that have been found to correlate with climate change denial and skepticism, opposition to fossil fuel taxation, and government interventionism. They identify a mixture of industrial masculinities and breadwinner masculinities to be consistent with CCM. Industrial/Breadwinner masculinities are hegemonic, and they are consistent with the dominant type of socialization that is imposed on men (Kivel, 2010, cited in Hultman \& Pulé, 2018). According to Paul Kivel (2010), boys and men are socialized to conform to certain malestream norms that are opposed to femininity (Hultman \& Pulé, 2018, p. 38). In fact, femininity is often used as an insult to the masculinities that result from this socialization, i.e., "don't be a girl". Emotional expressions such as love, compassion, and excitement, are considered feminine and therefore should not be embodied by men. Moreover, men are expected to be in control of situations, stand their ground, have homophobic and misogynistic ideals, and take responsibility for their families, friends and even nation (Hultman \& Pulé, p. 38). Hultman \& Pulé explain that this socialization derives into industrial/breadwinner masculinities, which are:

the very bedrock of male domination. Men socio-economically benefit the most from capitalism as well; traditional socialisations ... are designed to prepare males from an early age to do the structural bidding of commoditisation, effectively industrialising boys to become mechanistic men who are compelled to fall in line, be warriors willing to protect and become breadwinners able to provide for others. (Hultman \& Pulé, 2018, p. 40) 
Industrial masculinities refer to those who own and operate the means of production and extractivist corporations (Hultman \& Pulé, 2018, pp. 40-41). Some examples are fossil fuel executives, bankers, and corporate managers, all of which are most commonly embodied by Western white males. Breadwinner masculinities refer to "those working-class men that are typically found at the "coalface' of extractive practices" (Hultman \& Pulé, 2018, p. 41). This means that industrial/breadwinner masculinities are hegemonically embodied by (mostly) men of any social class, and they rely on eco-destructive practices that are profitable.

A concept that further explain this link is that of petro-masculinity (Daggett, 2018, p. 25), which "suggests that fossil fuels mean more than profit; fossil fuels also contribute to making identities, which poses risks for post-carbon energy politics". Thus, "taking petro-masculinity seriously means paying attention to the thwarted desires of privileged patriarchies as they lose their fossil fantasies" (Hultman \& Pulé, 2018, p. 44). In brief, climate action contrarianism is intertwined with a form of masculinity anchored in the industrial modernity, which the climate crisis is calling into question (Anshelm \& Hultman, 2014).

It has been shown that men are more insensitive to environmental risks than women, and white people have a lower environmental risk perception than people of color (Kahan et al., 2007; Krange et al., 2018). Flynn et al. (1994), Finucane et al. (2000) and Palmer (2003) studied this variation of risk perceptions across gender and race, identifying what is called the whitemale effect: "a distorting influence of [a] seemingly fearless group of men on the distribution of risk perceptions" (cited in Kahan et al. 2007, p. 466).

Kahan et al. (2007) have studied the cognitive structure underlining the white-male effect, identifying a form of motivated cognition which consists on protecting oneself from the identities one embodies and the roles one occupies. They call this mechanism identityprotective cognition and argue that, because white men have historically dominated oppressive systems such as capitalism and colonization, and because they are rewarded for their exploitative practices and their embodiment of industrial/breadwinner masculinities, their identity is often imbued by these same structures. Therefore, attacks on these structures are perceived as threats, as they affect their material conditions and personal identities ( $p$. 470). This explains white men's insensitivity to risk in comparison with the rest of the population, and their overt presence in the CCM. In fact, it is the same mechanism that makes this group of people uphold racial structures and xenosceptic views, that is, those based on the suspicion or dislike of immigrants combined with the belief that immigration rates are too high, and it can imply outward disdain towards immigrants and asylum seekers (Krange et al., 2018). However, there is one more dimension which intersects with gender and race in climate action obstructionism and which is essential to study the CCM: political ideology.

\subsection{Political ideology in the climate countermovement}

Different scholars have found certain political ideologies to be more correlated to the CCM than others. For example, Lockwood (2018) finds that, in Western European countries, "RWP is generally climate sceptical and hostile to climate policy, whereas [Left Wing Populism] is not" (p. 3). Moreover, Kulin et al. (2021) shows that nationalism, which is characterized by its concern with national interests over global issues, is correlated with climate change denial and skepticism. This is the opposite of cosmopolitanism, which takes all humanity to be one community, hence reinforcing world unity in place of antagonism between nations. 
Nationalism also entails "territorial autonomy or sovereignty" (Barrington 1997, cited in Kulin et al., 2021, p. 7), which means that it rejects international agreements that might breach this sovereignty. Since combating climate change requires the cooperation of different countries, and the arrangement of mitigation policies, this is not compatible with nationalist ideologies. In fact, "many policy analysts propose a precautionary approach that requires a high degree of interventionism and planning to promote the transformation of the fossil economy age into a renewable energy age" (Plewe, 2014, p. 103).

Ideologies such as RWP, Nationalism and Conservatism share their attempt to maintain the status quo, they are often authoritarian, hierarchical and individualistic, they frequently engage in climate change skepticism and denialism, they are usually hostile to fossil fuel taxation, and they distrust government regulation and intervention (Hultman et al., 2019; Kahan et al., 2007; Krange et al., 2018; Kulin et al., 2021; Lockwood, 2018; McCright \& Dunlap, 2011). In addition, these ideologies intersect with xenoscepticism, racial and gender discrimination. For example, Lockwood (2018) points out that RWP depends on what are constructed as "nefarious minorities", which are sources of corruption and which "draw the attention of the [elites] away from the 'deserving' but neglected people" (p. 2). This 'nefarious minority' is attributed to immigrants in contemporary Right Wing Populisms.

Furthermore, Neoliberal perspectives, in particular the defense and promotion of free-market autonomy, is very prominent in the CCM. Beder (2001) argues that conservative think tanks try to introduce neoliberal ideology into environmental policy, for example by "advocate[ing] the use of the market to allocate scarce environmental resources ... and promote replacement of legislation with voluntary industry agreements" (p. 128). CCM organizations are strongly connected with conservative right-wing think tanks, and these organizations are "key organizational components of a well-organized climate change counter-movement that has not only played a major role in confounding public understanding of climate science, but also successfully delayed meaningful government policy actions to address the issue" (Brulle, 2014, p. 681).

In the context of the Netherlands, there is a lack of specific research on the CCM. That may be explained by the lack of a strong opposition to climate science and policies among the population: $77 \%$ of Dutch people think that climate change impacts are an important challenge for the humanity, and $68 \%$ would welcome climate taxation on product and services (European Investment Bank, 2021). Under Mark Rutte, leader of the liberal-conservative Volkspartij voor Vrijheid en Democratie PVV and prime minister of The Netherlands since 2010, some steps have been taken in order to mitigate climate change. The Climate Act was passed in this country on July 2019. This binding law sets a medium run horizon of $49 \%$ reduction of greenhouse emissions by 2030, and carbon neutrality in the electricity sector by 2050 . The Dutch case has been of particular interest recently because of a court decision forcing the government to implement stern climate change mitigation measures (Buranyi, 2019). Also, a Dutch court also forced oil giant Shell to reduce its greenhouse gas emissions (BBC, 2021).

However, one interesting case of climate change denialism in The Netherlands that has already been documented is that of Thierry Baudet, founder of the FvD party. This political leader is known by its climate action contrarian stances, which include arguments such as climate change not being important, not clear, or not due to anthropogenic causes (Van der Wel, 
2019). During 2019, one of the FvD's most important campaign themes was attacking the Netherlands' climate law, for which it used a populist and anti-elitist argumentation (Van der Wel, 2019). This resonates with research on the expression of RWP stances based on a criticism to the elites in channels such as social media in the Netherlands (Fischer et al., 2020). However, there are cases of fake news on climate change expressed by politicians such as Baudet in social media, and it was discovered that users tended not to trust such messages and that those who believed in them could be limited to niche groups close to the extreme right wing (Van des Esschert, 2020). As will be explained below, the FVD party has maintained interactions with the climate action contrarian think tank CLINTEL, founded in 2019. This article seeks to make a contribution to the knowledge gap on CCM in the Netherlands by exploring this think tank and its link with FvD.

\section{METHODOLOGY}

Employing discourse analysis, I will examine the relationship between the micro-level discourses that are exemplified in each of the two media outputs chosen for the analysis, and the macro-level discourses "indicative of broader social patterns and practices" (LeGreco, 2014, p. 6).

In regards to the micro-level discourses, they will be analyzed using frame analysis, taking framing as "the process by which a communication source defines and constructs a political issue or public controversy" (Nelson et al., 1997, p. 567). Frame analysis is a prevalent methodological framework within studies in communication, and it has been used in a diversity of empirical studies in the field of climate change communication (i.e., Almiron et al. 2020; Mercado et al. 2019; Moreno \& Almiron, 2021).

Because of this, frame analysis is particularly insightful for the analysis of the discourse on climate (in)action and obstructionism. To do so, I will use the set of counter-frames developed by Almiron et al. (2020) which they employed to analyze the climate action contrarian discourse present in eight European think tanks (figure 1).

These counter-frames refer to ways of presenting information that "counter the consensus around anthropogenic climate change" (p. 7). Moreover, the frames encountered will be analyzed with the help of a table analysis of forty-two climate action contrarian claims formulated by Cook et al. (2018).

Regarding the macro-level discourse, in this case it refers to the gender and ideological underpinnings of the micro-level discourses. This part of the analysis draws upon the research outlined in the previous section and will highlight the presence or absence of characteristics ascribed to industrial/breadwinner masculinities and the political ideologies that have been explored. 
Box 1. An overview of the counter-frames analyzed

A. General scientific claims:

A1. Contesting IPCC legitimacy (implicitly or explicitly)A2. Contesting scientific consensus \& legitimacy (not IPCC)A3. Contesting scientific dissemination (by politicians, media, and other).

Examples: directly criticizing or casting doubts on IPCC reports and working groups, on other scientists or on disseminators because they are alarmist, models used are imperfect, models' predictions have faled, they misrepresent data, they are based on poor data, they use unreliable sources).

B. Specific scientific claims:

B4. It is not happening (climate change or global warming)B5. It is happening, but we do not know how serious it is or it is not seriousB6. It is happening, but it is good/not bad (either global warming or particular issues of it)B7. It is happening, but it is not us or it is not only us (other issues are also causes/main causes).

B8. It is happening, but we have other major problemsB9. It is happening, but any policy will be worse than warming.

Examples: It is not warming, Antarctic sea ice is increasing, it can be cyclical, temperature rise is marginal, $\mathrm{CO} 2$ is not bad, the Sun is the main cause, poverty and hunger are other equally major problems.

C. Non-scientific claims:

C10. Criticism of non-scientist defenders \& messages \& policies on a non-scientific basis.

C11. The text includes a neoliberal or a neoconservative economic position (supporting economic growth as the solution, markets self-regulation, minimum government intervention, no taxation of pollution, etc.)

C12. The text includes a mention to human population as a problem.

C13. The text includes a mention of animal-based diets or animal agriculture as a problem.

C14. The text trust technology as a solution to climate change or its consequences.

Examples of C10: Criticizing attitudes (ex: condescending, adamant, patronizing...), practices (ex: indoctrinating in schools and universities), goals (ex: profit-oriented, job-and career-oriented, or climate change defenders), consequences (ex: economic/environment/ethic consequences or climate change policies), ideology (ex: mentioning politics blamed as extremists or fanatics).

D. Focus.

D15. Policies/Solutions.

D16. Scientific approach.

D17. Economic approach.

D18. Ethical approach.

D19. Other.

Figure 1. Climate counterframes used in the analysis

Source: Almiron et al. (2020), p. 8.

\section{CASE STUDY}

As mentioned in the introduction, CLINTEL was founded in 2019 by professor of geophysics Guus Berkhout and journalist Marcel Crok, making it a very recent example of a climate action contrarian think tank in Europe. Their main stance is that "there is no climate emergency" and they believe the Intergovernmental Panel on Climate Change (IPCC) is exaggerating facts about climate change and attributing global warming to anthropogenic causes. The investigative platform Pointer (2020) analyzed a sample of 61 signers from The Netherlands. They found that this group of authors did not produce significant climate research, since only 15 publications in the area were found. In contrast, a random sample of 61 scientists attached to the IPCC published a quantity of 4.273 works in this area. This suggests that CLINTEL's supporters are not academics who produce climate change research.

Despite the climate expert scientific community having exposed the inaccuracy of these and other statements supported by denialist think tanks, CLINTEL gets enough support as to be in contact with Dutch Prime Minister Mark Rutte, to deliver their message to the UN, the European Parliament, and in international economic summits (van deer Waal \& Keizer, 2020, para. 2). According to van deer Waal \& Keizer (2020), CLINTEL's propositions are regularly 
quoted in the House of Representatives by Thierry Baudet, the leader of Forum Van Democratie (FvD), and they are part of a network with many well-known climate skeptics such as Theo Wolters, Kees le Pair and Fred Udo; former Shell employees such as Kees de Groot, Kees de Lange and Rutger van Santen, and Volkspartij voor Vrijheid en Democratie (VVD) top men such as Paul de Krom and Frits Bolkestein (para. 26). As figure 2 shows, the FvD clearly endorses CLINTEL's denial of the climate crisis. On November $20^{\text {th }}, 2019$, the MEPs that appear in figure 2 celebrated a forum in the European Parliament in which they invited CLINTEL in order to discuss their declaration against climate emergency.

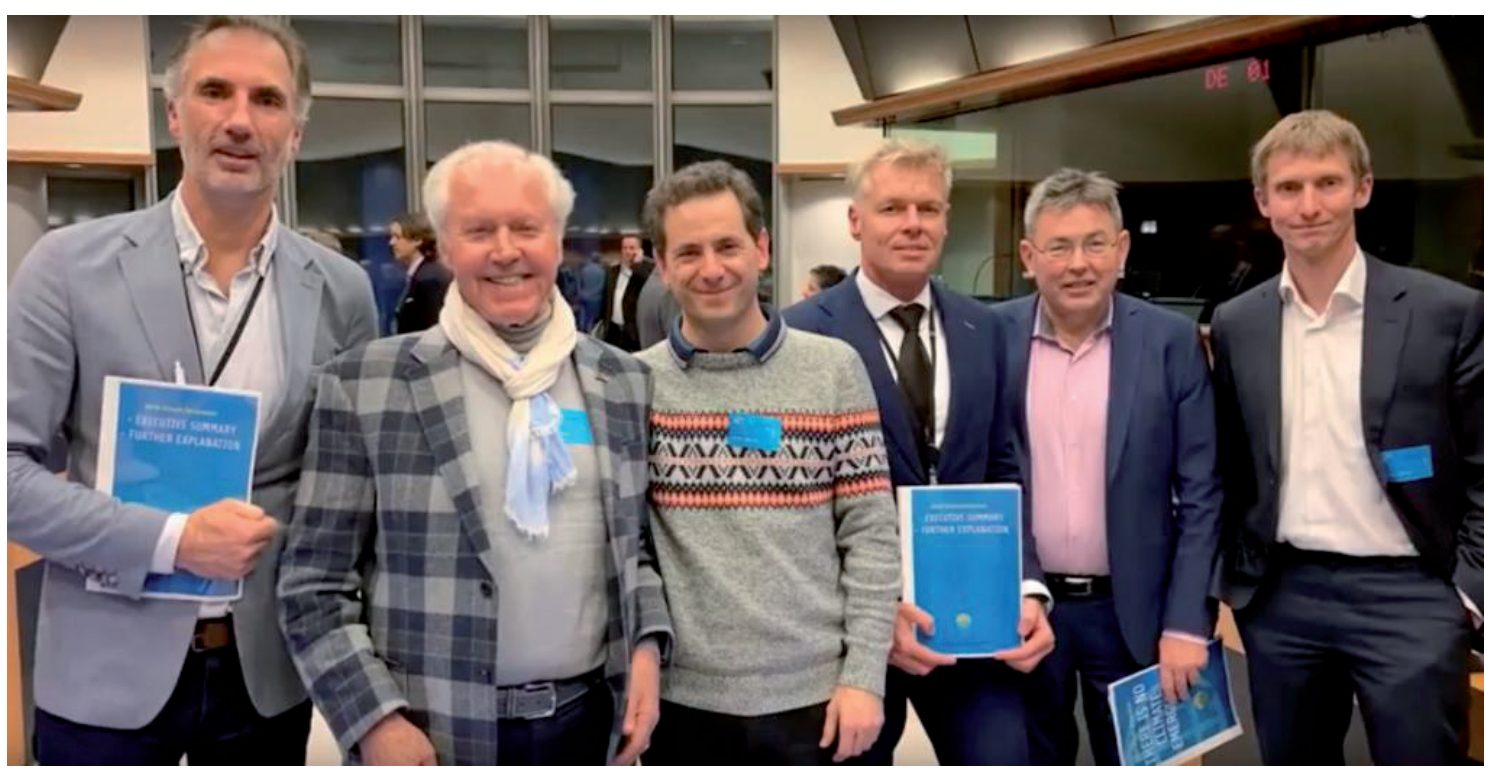

Figure 2. CLINTEL presents their essay to the European Parliament on November $20^{\text {th }}, 2019$. From left to right: Rob Rooken (FvD), Guus Berkhout (Clintel), Benoit Rittaud (L'association des ClimatosRéaliste), Rob Roos (FvD), Derk Jan Eppink (FvD) and Marcel Crok (Clintel). On December 20 ${ }^{\text {th }} 2020$, Rob Rooken, Rob Roos and Derk Jan Eppink joined JA21, a split from FvD. Source: Van der Waal \& Keizer (2020) in Pointer.

\subsection{CLINTEL's World Climate Declaration}

CLINTEL's core document is their World Climate Declaration, which states that "there is no climate emergency" (Pelser, 2021). This document has been signed by 914 professionals, including professors, scientists, and engineers. However, van deer Waal \& Keizer (2020) state that none of them are climate scientists (para. 44), and therefore, that CLINTEL misuses the undersigned's scientific title to make statements about a field that is not within their expertise. Furthermore, using Python and an Application Programming Interface that determines the most probable gender of a name (genderize.io), gender variation within the list of signatures were analyzed. As shown in figure 3, the result is that at least 810 signers are male (that is $88,33 \%$ of the sample), 48 signers are female $(5,23 \%)$, and 59 are unknown due to the absence of their first names in the declaration (6,43\%). The percentage of accuracy, that is, the degree of certainty of the assigned gender, is $97,24 \%$. 


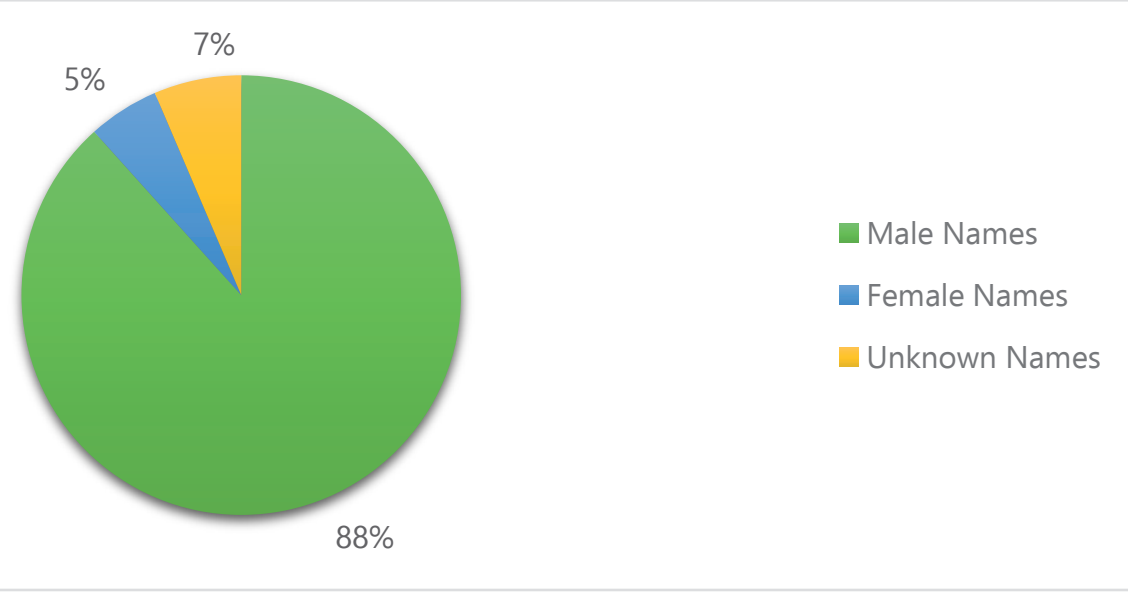

Figure 3. Gender Variation in CLINTEL's World Climate Declaration ( $n=914)$

Source: own elaboration.

This information is consistent with previous research on the CCM which has identified men to be more likely than other genders to engage in climate change contrarianism (Anshelm \& Hultman, 2014; Hultman \& Pulé, 2018; Hultman et al., 2019; Krange et al., 2018; Lockwood, 2018; McCright \& Dunlap, 2011).

The first claim in CLINTEL's World Climate Declaration is that "Natural as well as anthropogenic factors cause warming" (Pelser, 2021, p. 4). This means that CLINTEL does acknowledge anthropogenic global warming. However, by equating it with natural global warming, it proposes that humans are not the single cause of global warming (frame B7 from Almiron et al. 2020). However, the description of this section emphasizes the natural variation of Earth's climate across millennia, which diminishes the argument of anthropogenic factors, and it uses the Little Ice Age as the explanation as to why we are experiencing global warming (B6).

The second claim is that "warming is far slower than predicted" (Almiron et al., p. 4). Here they are contesting the IPCC legitimacy (A1), indicating that "the world has warmed significantly less than predicted by IPCC" (p. 4). However, Björn Stevens of the Max Planck Institute for Meteorology in Hamburg points out that there are errors in the method that Marcel Crok (CLINTEL's co-founder) and Nic Lewis developed to assess warming. Nevertheless, Guido van der Werf, Earth science professor at the Vrije Universiteit Amsterdam, used a similar method arriving at a warming that is hardly slower than the IPCC models indicate (Keulemans, 2018).

The third claim is that "climate policy relies on inadequate models" (Pelser, 2021, p. 4) (A1). This claim relies on the fallacy of impossible expectations. It is based on the idea that models need to be perfect to be reliable, which is an impossible expectation "no model is perfect as they are simplified representations of reality ... models are useful tools based on fundamental physical principles that can reproduce the past and provide insights into the future" (Cook et al. 2018).

The fourth claim is that "CO2 is plant food, the basis of all life on Earth" (Pelser, 2021, p. 4) (B6). This statement falls into the fallacy of slothful induction: it is based on the idea that plants need $\mathrm{CO} 2$ to grow, which is true, however it assumes that greenhouse warming has no negative impacts on plants, which is far from the truth (Cook et al. 2018).

The fifth claim is that "global warming has not increased natural disasters" (B6), and it specifies that "CO2-mitigation measures are as damaging as they are costly" (Pelser, 2021, p. 4) (B9). 
According to IPCC predictions and to the Organization for Economic Co-operation and Development (OECD) in their report Climate change: Consequences of inaction (OECD, n.d.), global warming will indeed cause natural disasters related to the water level rising, precipitation patterns, risk of floods and draught, and these consequences will be much more costly than mitigation and climate action.

The last claim of the declaration is that "climate policy must respect scientific and economic realities" (Pelser, 2021, p. 4), where they advocate for adaptation instead of mitigation measures (C11). Moreover, they specifically state that they "strongly oppose the harmful and unrealistic net-zero CO2 policy proposed for 2050" (p. 4). These statements reflect a neoliberal ideology that supports economic growth as a solution, opposes government intervention, and critiques fossil fuel taxation, all of which were analyzed in the literature review in connection with political ideologies and industrial/breadwinner masculinities.

In sum, CLINTEL's World Climate Declaration uses five counter-frames: It contests the IPCC legitimacy (A1), states that global warming is happening, but it is good or not bad (B6), states that global warming is happening, but we are either not causing it or not the only ones causing it (B7), states that global warming is happening but any policy will be worse than global warming (B9), and it includes a neoliberal or a neoconservative economic position supporting economic growth as the solution, markets self-regulation, minimum government intervention, no taxation of pollution, etc. (C11).

\subsection{Press conference}

On November $20^{\text {th }}$ of 2019, CLINTEL'S founder and ambassadors Guus Berkhout and Marcel Crok among others presented their World Climate Declaration at the European Parliament, hosted by the European Conservatives and Reformists group. CLINTEL published a post on November $23^{\text {rd }}$ which includes a video taken by the Global Warming Policy Foundation, another climate action obstructionist think tank, during this press conference. In the video, we can observe the discussion of several men who are either part of or sympathizers of CLINTEL, arguing against Irina von Wiese, a British politician and Liberal Democrat who was a Member of the European Parliament at the time (see Appendix B for a transcript). In regards to gender and race, there were eight white men from CLINTEL; twelve white men and one white woman in the opposite table, where one of them actively supported CLINTEL; one man of color and one white man sitting on the left of von Wiese, and von Wiese herself (white woman). Von Wiese expresses her fear to the impact that CLINTEL's climate change contrarian arguments might have in the development of the climate crisis, worrying that their perspectives shared by others will lead to an irreversible state of environmental disaster. Before diving closely into the content of the video, it is important to point out that this video was cut in ways that a lot of information was lost. I will point out these instances and their possible impact.

Irina von Wiese is the first person to speak in the video. However, it is clear that she is reacting to CLINTEL's declaration which they exposed beforehand. Unfortunately, we do not have that part of the session, so we cannot know what they said exactly. Nevertheless, we have their World Climate Declaration, which has been previously analyzed, to account for their general ideas. Von Wiese explains that she is flabbergasted by the fact that they were attending an event stating that there is no climate emergency. She proceeds in a very polite way, stating her belief in freedom of speech and her respect to their opinion. She then articulates arguably 
condescending sentences: "I wish you were right" and "I wish I could believe like some of you apparently do" (0:35), however there is a cut in the video between these utterances, so we do not know whether she mentioned specific points that they brought up or not. She then goes on to indicate that:

Unfortunately, there is something like a difference between truth and untruth, and we do have overwhelming scientific evidence: There is man-made climate emergency today and denying it is, of course, anybody's free opinion. (0:58, emphasis added).

Stating that there is overwhelming (expert) scientific evidence for a man-made climate emergency already debunks CLINTEL's declaration and ideals if it is true. In the literature review, we have explored this statement finding it to be true, therefore she is offering reliable information at this point in the video. Von Wiese goes on:

But it is a bit like closing your eyes when you see a train speeding in your direction and say: "Oh, it is not coming, is it?" And the problem is, it's not just you. It is our future generation. Probably our generation, however old, we already suffer. But certainly the generation of our children. And denying that it exists today is equivalent to some form of collective manslaughter on another generation. I don't know how many of you agree with what we've just heard. Maybe we'll have a show of hands. (1:14).

What von Wiese is saying here is that the climate emergency is clear, and that if there are no measures taken fast enough to decrease future global warming and mitigate its effects, this will result in the death of many people. This is consistent with IPCC predictions which show that, if we do not prevent global warming from reaching an increase of $2 \stackrel{ }{a} \mathrm{C}$ or more, this will cause flooding, draught, rising sea levels leading to natural disasters, and damage to the Earth's biodiversity, among others (IPCC, 2018). After von Wiese states these words, the men from CLINTEL look to one another full of surprise, with open mouths, raising their hands in the air accompanied with incredulous facial expressions. After Von Wiese is done talking, Berkhout intercedes:

May I ask you a question? I hear many remarks from people like you. I feel sorry for you because I only hear emotions. I only hear emotions and I don't hear facts. If you look at the facts that we then not go to the future, but look in the past, yeah. If we looked in the past, let's say the last 70 years. Tell me one thing about what, this temperature increase has done for bad in our society. Please tell me [scene cut]. (2:26)

First of all, here we have an example of embodiment of industrial/breadwinner masculinities which are defined by their opposition to ideas that are considered feminine (Hultman \& Pulé, 2018). Emotions are here targeted and negatively marked, used in a patronizing and condescending manner by white men towards a white woman. Secondly, in her speech, von Wiese refers to the existence of overwhelming scientific evidence that corroborates we are in an environmental crisis caused by anthropogenic global warming. This is indeed the case, and there is such a high consensus on the topic that denying it brings the discourse to a much earlier stage where climate science experts did not have the information they have now. Thirdly, Berkhout proposes to look at the past instead of the future, which diverts from the urgency of climate action to mitigate the effects of global warming in the future. Cook et al. (2018) call this fallacy "red herring". Berkhout finishes by asking her to answer his question, but there is a cut in the video that prevents us from knowing her answer, if there was one. 
After this, Marcel Crok intervenes, adding that the IPCC "acknowledged that there is no trend in flooding worldwide" $(3: 25)$ and that they are hiding this information from the public, to which von Wiese interrupted:

\section{IRINA VON WIESE:}

I'm sorry, but I need to correct you here. What you just said is not correct. I would invite you to please [interrupted] [unintelligible] *from the IPCC that they have said this*.

MARCEL CROK:

*So you're so you. So you're so you're* denying IPCC

IRINA VON WIESE:

I am denying that the IPCC the has ever made such a statement [interrupted,

*unintelligible*]

\section{MARCEL CROK:}

*Wow. I will send you* I will send you the references after this meeting.

IRINA VON WIESE:

Yes, please, thank you. (4:03)

In this excerpt and after having looked at previous parts of the debate, it become clear that the ways in which von Wiese and the CLINTEL ambassadors communicate their ideas are very different in terms of politeness and respect. Whereas she apologizes when interrupting Crok and includes conciliatory words such as 'please', 'invite' or 'thank you', Crok does not let her finish the answer to his question and reacts with a 'wow' when she is able to clarify. This is again an example of condescending and paternalistic behavior that stands out particularly because the three men who speak in this video engage in it. Moreover, the IPCC has carried out vast research underlining the relation between climate events and natural disasters (Seneviratne, 2012), which exposes the fact that, if what he is saying is correct, he was 'cherry picking' (Cook et al., 2018).

The last person to speak is also a white man. He says:

I have two questions about the graph that you showed [to CLINTEL's ambassadors], but I'm sorry I didn't want to respond before my questions to what you've said [to von Wiese]. We've just all observed the way in which your emotions clouds your ability to listen. Professor Berkhout did not deny man made climate change. He specifically said he accepted it and you have sat here and told him he is denying man made climate change. His first point was that, yes, there is that man-made climate change, but that the question is, is it $90 \%$ or $10 \%$ ? We all held that. So why are you saying he didn't? He's denying it. He's not denying it. [End] (4:31).

Again, we are presented with a very condescending and patronizing treatment that is further unjustified by the fact that he is accusing von Wiese of stating that Berkhout denied man-made climate change, when what she stated is that he denied man-made climate emergency. It seems like the three male speakers have not been very able to listen either, but that is not criticized or highlighted by anybody. Then this speaker goes on to indicate that anthropogenic climate change corresponds only to the $10 \%$, which has repeatedly been shown to be 
incorrect. The video ends with the speaker's question, not giving von Wiese the opportunity to respond, so we do not know if this happened and how it looked like if it did.

Lastly, I want to point out the title of CLINTEL's post where this video appears: "At a press conference on Wednesday (20th November), the European Parliament was told: 'there is no climate emergency'. One MEP became emotional and accused the organisers of 'collective manslaughter' on future generations" (Crok, 2019). This emphasis on the attribution of negative connotations to 'emotional' is in itself a patriarchal misogynistic endeavor. This video is a perfect example of the gender and power dynamics that are taking place in this debate. Moreover, it reinforces industrial/breadwinner masculinities, the hegemony of white men, and the development of conservative Right Wing ideologies that is threatening to increase social injustice and environmental disasters.

\section{CONCLUSION AND DISCUSSION}

In conclusion, the intersection between gender and political ideology has proven highly relevant in the analysis of the climate change countermovement (CCM). The impact of hegemonic male socializations has led to the development of eco-destructive industrial/breadwinner masculinities. These masculinities complicate what Kahan et al. (2007) calls identity-protective cognition, as they tie men's identities to exploitative and oppressive practices that derived into a colonialist patriarchal society.

This, together with the fact that white men still occupy most positions of power, hinders the progress to be made in terms of egalitarianism as well as ecological action. Right Wing Populisms, reinforced by Nationalist ideologies, have encouraged xenosceptic discrimination as well as the rejection of climate change mitigation policies and measures, with a special focus on the protection of fossil fuel industries. Since white people and xenosceptic ideologies have been found to correlate to the CCM (Krange et al., 2018; Kahan et al., 2007), future research should address the relationship between xenoscepticism and climate obstructionism. In this paper, the fact that the CLINTEL forum as well as any other climate change contrarians who speak in the video analyzed are white men reminds us of the white-male effect discussed in Kahan et al. (2007), as it is these same white men the ones who show insensitivity to environmental risk perception, in contrast with von Wiese, the only woman who speaks in the video. This is an interesting correlation that is not conclusive, as much deeper research would be needed to investigate racial biases within this organization and others with the same profile. Moreover, climate action contrarian think tanks have contributed to the spreading of misinformation regarding climate change and anthropogenic global warming, feeding into the Right Wing political discourse in Western European countries.

The Netherlands in particular remains an underrepresented and under-researched country in terms of climate action contrarianism despite the countermovement being strong enough to bring forth one of the newest climate action contrarian think tanks in Europe, CLINTEL. Through the analysis of two outputs by CLINTEL, their counter-frames have been analyzed and their misinforming statements, debunked. In addition, we have seen the correlation between the analyzed intersections of gender and political ideology, and the material that CLINTEL brings forward. Specifically obvious is the domination of white male identities that shame and patronize people whom they consider have feminine traits, such as being emotional. 
This study has attempted to highlight the importance of studying the aforementioned intersections in relation to the CCM, and to encourage further research into the state of affairs in The Netherlands, including the contrarian think tank CLINTEL.

\section{References}

Abelson, D. E. (2018). Do think tanks matter?: Assessing the impact of public policy institutes (3rd ed.). McGill-Queen's University Press.

Almiron, N. (2016). Think tanks y neoliberalismo. In F. Sierra Caballero \& F. Maniglio (Eds.), Capitalismo financiero y comunicación (pp. 195-220). Ediciones Ciespal.

Almiron, N. (2017). Favoring the elites: Think tanks and discourse coalitions. International Journal of Communication, 11, 4350-4369.

Almiron, N., \& Xifra, J. (2020). Climate change denial and public relations. Strategic communication and interest groups in climate inaction. Routledge.

Almiron, N., Boykoff, M., Narberhaus, M., \& Heras, F. (2020). Dominant counter-frames in influential climate contrarian European think tanks. Climatic Change, 162(4), 2003-2020. https://doi.org/10.1007/s10584-020-02820-4

Almiron, N., \& Moreno, J. A. (2021). Think tanks neoliberales y falsos debates: La propuesta del impuesto a la carne para combatir la crisis climática [Neoliberal think tanks and false debates: The meat tax proposal to combat the climate crisis]. In D. Rodrigo-Cano, R. Mancinas-Chávez, \& R. Fernández-Reyes (Eds.), La comunicación del cambio climático, una herramienta ante el gran desafío (pp. 222-248). Dykinson. https://bit.ly/321QzJY

Anshelm, J., \& Hultman, M. (2014). A green fatwā? Climate change as a threat to the masculinity of industrial modernity. Norma, 9(2), 84-96. https://doi.org/10.1080/18902138.2014.908627

Beder, S. (2001) Research note - Neoliberal Think Tanks and Free Market Environmentalism, Environmental Politics, 10(2), 128-133. https://doi.org/10.1080/714000530

Brulle, Robert J. 2014. Institutionalizing Delay: Foundation Funding and the Creation of U.S. Climate Change Counter-Movement Organizations. Climatic Change, 122(4), 681-694. https://doi.org/10.1007/s10584-013-1018-7

BBC (2021, May 26). Shell: Netherlands court orders oil giant to cut emissions. BBC. https://bbc.in/30vPIBa

Buranyi, Stephen (2020, May 20). Climate action under duress: how Dutch were forced into emissions cuts. The Guardian. https://bit.ly/31XGyOj

Cook, J., Ellerton, P., \& Kinkead, D. (2018). Deconstructing climate misinformation to identify reasoning errors. Environmental Research Letters, 13(2), 024018. https://doi.org/10.1088/17489326/aaa49f

Crok, M. (2019, November 23). European Parliament told: There is no climate emergency. CLINTEL. https://bit.ly/3GK7ccw

Daggett, C. (2018). Petro-masculinity: Fossil fuels and authoritarian desire. Millennium: Journal of International Studies, 47(1), 25-44. https://doi.org/10.1177/0305829818775817

European Investment Bank (2021). Majority (62\%) of Dutch people think their country will fail to drastically reduce carbon emissions by 2050. European Investment Bank. https://bit.ly/31P9Vm9

Fischer, A., Brands, C., \& Abadi, D. (2020). The Expression of Right-Wing Populism in the Netherlands across Facebook Posts [Preprint]. Open Science Framework. https://doi.org/10.31219/osf.io/35puf

Hofkens, A., \& van der Waal, W. (2020). Klimaatsceptisch rapport Clintel krijgt geen steun van klimaatonderzoek [Climate skeptical report Clintel gets no support from climate research]. Pointer. https://bit.ly/3dOg8ku 
Hultman, M., Björk, A., \& Viinikka, T. (2019). The Far Right and Climate Change Denial. In B. Forchtner (Ed.), The Far Right and the Environment (pp. 121-135). Routledge. https://doi.org/10.4324/9781351104043-8

Hultman, M., Pulé, P. M. (2019). Ecological Masculinities: Theoretical foundations and practical guidance. Routledge. https://doi.org/10.4324/9781315195223

IPCC (2018). Special Report Global Warming of $1.5^{\circ} \mathrm{C}$. IPCC. https://bit.ly/3IZZexQ

Jacques, P. J., Dunlap, R. E., \& Freeman, M. (2008). The organisation of denial: Conservative think tanks and environmental scepticism. Environmental Politics, 17(3), 349-385. https://doi.org/10.1080/09644010802055576

Kahan, D. M., Braman, D., Gastil, J., Slovic, P., \& Mertz, C. K. (2007). Culture and identity-protective cognition: Explaining the white-male effect in risk perception. Journal of Empirical Legal Studies, 4(3), 465-505. https://doi.org/10.1111/j.1740-1461.2007.00097.x

Keulemans, M. (2018, February 28). De klimaatjournalist die in de ban van het tegengeluid raakte: 'Ik ben een roepende in de woestijn geworden' [The climate journalist who fell under the spell of dissent: 'I have become a voice in the wilderness']. deVolkskrant. https://bit.ly/3DVZ5rt

Krange, O., Kaltenborn, B. P., \& Hultman, M. (2019). Cool dudes in Norway: Climate change denial among conservative Norwegian men. Environmental Sociology, 5(1), 1-11. https://doi.org/10.1080/23251042.2018.1488516

Kulin, J., Johansson Sevä, I., \& Dunlap, R. E. (2021). Nationalist ideology, rightwing populism, and public views about climate change in Europe. Environmental Politics, 1-24. https://doi.org/10.1080/09644016.2021.1898879

Leiserowitz, A., Maibach, E., Roser-Renouf, C., Feinberg, G., \& Rosenthal, S. (2015). Climate change in the American mind: March, 2015. Yale Project on Climate Change Communication. https://bit.ly/3m6TNDs

LeGreco, M. (2014). Discourse analysis. In J. Mills \& M. Birks (Eds.) Qualitative methodology, (pp. 67-88). SAGE Publications, Inc., https://dx.doi.org/10.4135/9781473920163

Lockwood, M. (2018). Right-wing populism and the climate change agenda: Exploring the linkages. Environmental Politics, 27(4), 712-732. https://doi.org/10.1080/09644016.2018.1458411

Lynas, M., Houlton, B. Z., \& Perry, S. (2021). Greater than 99\% consensus on human caused climate change in the peer-reviewed scientific literature. Environmental Research Letters, 16(11), 114005. https://doi.org/10.1088/1748-9326/ac2966

McCright, A. M., \& Dunlap, R. E. (2011). Cool dudes: The denial of climate change among conservative white males in the United States. Global Environmental Change, 21(4), 1163-1172. https://doi.org/10.1016/j.gloenvcha.2011.06.003

Mercado-Sáez, M.-T., Marco-Crespo, E., \& Álvarez-Villa, À. (2019). Exploring news frames, sources and editorial lines on newspaper coverage of nuclear energy in Spain. Environmental Communication, 13(4), 546-559. https://doi.org/10.1080/17524032.2018.1435558

Moreno, J. A., \& Almiron, N. (2021). Representación en la prensa española del papel de la agricultura animal en la crisis climática: Falta de visibilidad y carnismo [Representation of the role of animal agriculture in the climate crisis in the Spanish press: Lack of visibility and carnism]. Estudios Sobre El Mensaje Periodístico, 27(1), 349-364. https://doi.org/10.5209/esmp.73745

Nelson, T., Clawson, R., \& Oxley, Z. (1997). Media framing of a civil liberties conflict and its effect on tolerance. The American Political Science Review, 91(3), 567-583. https://doi.org/10.2307/2952075

OECD (n.d.). Climate change: Consequences of inaction. Organisation for Economic Co-operation and Development. https://bit.ly/31Pm9LD

Oreskes, N., \& Conway, E. M. (2011). Merchants of Doubt. Bloomsbury Publishing.

Pelser, B. (2021). World Climate Declaration. CLINTEL. https://bit.ly/3sldP11 
Piltz, R. (2008). 'The Denial Machine'. Index on Censorship, 37(4), 72-81. https://doi.org/10.1080/03064220802561366

Plehwe, D. (2014). Think tank networks and the knowledge-interest nexus: The case of climate change. Critical Policy Studies, 8(1), 101-115. https://doi.org/10.1080/19460171.2014.883859

Plehwe, D. (2021). Think tanks and the politics of climate change. In D. Abelson \& C. Rastrick (Eds.) Handbook on Think Tanks in Public Policy, (pp. 150-165). Edward Elgar Publishing. https://doi.org/10.4337/9781789901849.00022

Van der Wel, R. (2019). Strategies of climate change denial: The case of Thierry Baudet. MaRBLe, 1, 116. https://doi.org/10.26481/marble.2019.v1.750

\section{About the author}

Mayte Moreno-Soldevila is a researcher with an intersectional approach who is currently furthering her studies in both the research Master in Arts, Media and Literary Studies at the University of Groningen, and a Psychology degree at the Spanish Universidad Nacional de Educación a Distancia. Moreover, she recently taught the bachelor course Intersectionality and Superdiversity at the University of Groningen as part of the Minorities and Multilingualism program. With a particular interest in Feminist \& Gender Theory, Post-colonialist Studies, Migration Studies and Environmental Studies, her research and academic profile aims to offer a deeper understanding of the intersections between various societal issues. 